\title{
Lanthanide Complexes of Substituted $\beta$-Diketone Hydrazone Derivatives: Synthesis, Characterization, and Biological Activities
}

\author{
W. H. Hegazy ${ }^{1,2}$ and I. H. Al-Motawaa ${ }^{1}$ \\ ${ }^{1}$ Chemistry Department, College of Science, King Faisal University, Al-Ahsa 31982, Saudi Arabia \\ ${ }^{2}$ College of Science, Suez Canal University, Suez, Egypt \\ Correspondence should be addressed to W. H. Hegazy, whchemistry@hotmail.com
}

Received 11 March 2011; Accepted 26 April 2011

Academic Editor: Lorenzo Pellerito

Copyright (C) 2011 W. H. Hegazy and I. H. Al-Motawaa. This is an open access article distributed under the Creative Commons Attribution License, which permits unrestricted use, distribution, and reproduction in any medium, provided the original work is properly cited.

\begin{abstract}
A series of $\beta$-diketone hydrazone derivatives have been synthesized through condensation of $\beta$-diketone with aromatic aldehydes followed by reaction with phenylhydrazine. The structure of the ligands and intermediates are well defined through elemental and spectroscopic analyses. These hydrazones are potential ligands toward lanthanide metal ions. New complexes of trivalent Scandium, Yttrium, Lanthanum, and Cerium have been synthesized. The composition of these complexes is discussed on the basis of elemental analyses, IR, magnetic moments, and thermal analyses. The prepared complexes were screened for antibacterial and antifungal properties and have exhibited potential activity.
\end{abstract}

\section{Introduction}

Metal complexes of Schiff bases occupy a central role in coordination chemistry for analytical, physical, and biochemical purposes [1-19]. Many complexation process of $\beta$-diketones Schiff bases and/or hydrazones with lanthanide metal ions have been synthesized and characterized by elemental analysis, DTA-TG, X-ray, IR, fluorescence, UV spectra, and molar conductance [20-31]. Biochemical activities of some complexes were reported [15].

The present investigation deals with the preparation of some new $\beta$-diketone dihydrazone derivatives $\left(L^{1}-L^{12}\right)$ and their mononuclear $\mathrm{Sc}(\mathrm{III}), \mathrm{Y}(\mathrm{III}), \mathrm{La}(\mathrm{III})$, and $\mathrm{Ce}(\mathrm{III})$ complexes. The prepared ligands were characterized by elemental analysis, IR, ${ }^{1} \mathrm{H}$ NMR, and mass spectra. Elemental analysis, IR, magnetic susceptibility measurements, TG, and conductivity measurements characterize the prepared complexes. The antibacterial activities of the prepared complexes were assessed against Gram-positive bacteria B. subtilis and S. aureus and Gram-negative bacteria E. coli and S. typhi. Prepared complexes were also screened for their antifungal activities against two fungi (A. niger and C. albicans).

\section{Results and Discussion}

The synthesized ligands $L^{1}-L^{12}$ were characterized by their physical properties, elemental analyses, IR Spectra, ${ }^{1} \mathrm{H}$ NMR, and mass spectra. The data are given in Tables $1-4$, respectively. Figure 1 represents tautomerization of the ligands.

The elemental analyses of the ligands, Table 1 , were found in good agreement with the calculated data $( \pm 0.9 \%)$.

The infrared spectra of the ligands show broad bands in the region $3449.46-3208.93 \mathrm{~cm}^{-1}$ assigned to $\mathrm{N}-\mathrm{H}$ stretching vibrations, strong-intensity bands in the region 1601.2$1594.04 \mathrm{~cm}^{-1}$ assigned to $\mathrm{C}=\mathrm{N}$ stretching vibrations, strongintensity bands in the region $1502.21-1442.31 \mathrm{~cm}^{-1}$ assigned to interaction (coupling) between $\mathrm{C}-\mathrm{N}$ stretching and $\mathrm{N}-$ $\mathrm{H}$ bending vibrations of the $\mathrm{C}-\mathrm{H}-\mathrm{N}$ group, and mediumintensity bands in the region $1376.13-1320.88 \mathrm{~cm}^{-1}$ assigned to $\mathrm{N}=\mathrm{N}$ asymmetric stretching vibrations of the azoform of the ligands which formed as a result of the azo-hydrazo tautomerism [21]. Substitutions at the ortho- and parapositions enhance the mesomeric effect, which activate azohydrazo tautomerism. Weak intensity bands in the region $1281.66-1182.83 \mathrm{~cm}^{-1}$ are assigned to $\mathrm{N}-\mathrm{H}$ inplane bending 
TABLe 1: Physical properties and elemental analyses of the ligands.

\begin{tabular}{|c|c|c|c|c|c|c|}
\hline & \multirow{2}{*}{ Color } & \multirow{2}{*}{ Yield $\%$} & \multirow{2}{*}{$\mathrm{MP} /{ }^{\circ} \mathrm{C}$} & \multicolumn{3}{|c|}{ Elemental analyses found (calc.) } \\
\hline & & & & $\% \mathrm{C}$ & $\% \mathrm{H}$ & $\% \mathrm{~N}$ \\
\hline $\begin{array}{l}L_{1} \cdot 4 \mathrm{H}_{2} \mathrm{O} \\
\mathrm{C}_{24} \mathrm{H}_{23} \mathrm{~N}_{4} \mathrm{~F} \\
460.46\end{array}$ & Yellow & 81 & 213 & $\begin{array}{c}62.88 \\
(61.65)\end{array}$ & $\begin{array}{c}6.95 \\
(6.75)\end{array}$ & $\begin{array}{c}12.23 \\
(12.36)\end{array}$ \\
\hline $\begin{array}{l}L_{2} \cdot 7 \mathrm{H}_{2} \mathrm{O} \\
\mathrm{C}_{24} \mathrm{H}_{23} \mathrm{~N}_{4} \mathrm{Cl} \\
530.8\end{array}$ & Yellow & 83 & 238 & $\begin{array}{c}54.49 \\
(54.40)\end{array}$ & $\begin{array}{c}7.00 \\
(6.74)\end{array}$ & $\begin{array}{c}10.60 \\
(11.36)\end{array}$ \\
\hline $\begin{array}{l}L_{3} \\
\mathrm{C}_{24} \mathrm{H}_{23} \mathrm{~N}_{4} \mathrm{Br} \\
447.36\end{array}$ & Yellow & 80 & 188 & $\begin{array}{c}64.43 \\
(63.69)\end{array}$ & $\begin{array}{c}5.14 \\
(500)\end{array}$ & $\begin{array}{c}12.51 \\
(11.37)\end{array}$ \\
\hline $\begin{array}{l}L_{4} \\
\mathrm{C}_{24} \mathrm{H}_{23} \mathrm{~N}_{5} \mathrm{O} \\
397.41\end{array}$ & Orange-red & 79 & 163 & $\begin{array}{c}69.60 \\
(69.73)\end{array}$ & $\begin{array}{c}5.30 \\
(5.57)\end{array}$ & $\begin{array}{c}16.50 \\
(16.95)\end{array}$ \\
\hline $\begin{array}{l}L_{5} \cdot 3 \mathrm{H}_{2} \mathrm{O} \\
\mathrm{C}_{29} \mathrm{H}_{23} \mathrm{~N}_{4} \mathrm{~F} \\
502\end{array}$ & Dark-green & 88 & 225 & $\begin{array}{c}69.31 \\
(68.87)\end{array}$ & $\begin{array}{c}6.17 \\
(6.17)\end{array}$ & $\begin{array}{c}11.15 \\
(10.67)\end{array}$ \\
\hline $\begin{array}{l}L_{6} \cdot 3 \mathrm{H}_{2} \mathrm{O} \\
\mathrm{C}_{29} \mathrm{H}_{25} \mathrm{~N}_{4} \mathrm{Cl} \\
518.88\end{array}$ & Light-pink & 74 & 216 & $\begin{array}{c}67.18 \\
(66.64)\end{array}$ & $\begin{array}{c}5.97 \\
(5.22)\end{array}$ & $\begin{array}{c}10.81 \\
(10.41)\end{array}$ \\
\hline $\begin{array}{l}L_{7} \\
\mathrm{C}_{29} \mathrm{H}_{23} \mathrm{~N}_{4} \mathrm{Br} \\
509.43\end{array}$ & Light-pink & 74 & 20 & $\begin{array}{c}68.42 \\
(69.13)\end{array}$ & $\begin{array}{c}4.95 \\
(5.26)\end{array}$ & $\begin{array}{c}10.99 \\
(10.17)\end{array}$ \\
\hline $\begin{array}{l}L_{8} \cdot 3 \mathrm{H}_{2} \mathrm{O} \\
\mathrm{C}_{29} \mathrm{H}_{25} \mathrm{~N}_{5} \mathrm{O}_{2} \\
530\end{array}$ & Orange & 67 & 231 & $\begin{array}{c}65.78 \\
(65.05)\end{array}$ & $\begin{array}{c}5.86 \\
(5.25)\end{array}$ & $\begin{array}{c}13.23 \\
(13.31)\end{array}$ \\
\hline $\begin{array}{l}L_{9} \\
\mathrm{C}_{34} \mathrm{H}_{27} \mathrm{~N}_{4} \mathrm{~F} \\
510.59\end{array}$ & Pale-beige & 70 & 138 & $\begin{array}{c}80.00 \\
(80.90)\end{array}$ & $\begin{array}{c}5.32 \\
(5.32)\end{array}$ & $\begin{array}{c}10.97 \\
(10.95)\end{array}$ \\
\hline $\begin{array}{l}L_{10} \\
\mathrm{C}_{34} \mathrm{H}_{27} \mathrm{~N}_{4} \mathrm{Cl} \\
527.04\end{array}$ & Beige & 88 & 143 & $\begin{array}{c}77.48 \\
(76.61)\end{array}$ & $\begin{array}{c}5.15 \\
(4.82)\end{array}$ & $\begin{array}{l}10.63 \\
(9.99)\end{array}$ \\
\hline $\begin{array}{l}L_{11} \\
\mathrm{C}_{34} \mathrm{H}_{27} \mathrm{~N}_{4} \mathrm{Br} \\
571.47\end{array}$ & Beige & 65 & 173 & $\begin{array}{c}71.46 \\
(71.46)\end{array}$ & $\begin{array}{c}4.75 \\
(5.31)\end{array}$ & $\begin{array}{c}9.80 \\
(9.72)\end{array}$ \\
\hline $\begin{array}{l}L_{12} \\
\mathrm{C}_{34} \mathrm{H}_{27} \mathrm{~N}_{5} \mathrm{O}_{2} \\
537.58 \\
\end{array}$ & Orange & 70 & 190 & $\begin{array}{c}75.00 \\
(74.25)\end{array}$ & $\begin{array}{c}5.03 \\
(5.22)\end{array}$ & $\begin{array}{c}13.03 \\
(12.65)\end{array}$ \\
\hline
\end{tabular}

TABLE 2: Selected infrared data of the ligands $\left(\mathrm{cm}^{-1}\right)$.

\begin{tabular}{|c|c|c|c|c|c|c|}
\hline & $v(\mathrm{~N}-\mathrm{H})$ & $v(\mathrm{C}=\mathrm{N})$ & $v(\mathrm{C}-\mathrm{N}) \delta(\mathrm{N}-\mathrm{H})$ & $v(\mathrm{~N}=\mathrm{N})$ & $\delta(\mathrm{N}-\mathrm{H})$ & $v(\mathrm{~N}-\mathrm{N})$ \\
\hline$L_{1}$ & 3431 & 1600 & 1456 & 1373 & 1222 & 1072 \\
\hline$L_{2}$ & 3430 & 1598 & 1443 & 1376 & 1249 & 1071 \\
\hline$L_{3}$ & 3421 & 1598 & 1487 & 1375 & 1247 & 1072 \\
\hline$L_{4}$ & 3433 & 1601 & 1442 & 1375 & 1192 & 1080 \\
\hline$L_{5}$ & 3447 & 1598 & 1502 & 1365 & 1226 & 1098 \\
\hline$L_{6}$ & 3429 & 1596 & 1497 & 1364 & 1221 & 1070 \\
\hline$L_{7}$ & 3449 & 1594 & 1454 & 1359 & 1211 & 1066 \\
\hline$L_{8}$ & 3346 & 1597 & 1444 & 1346 & 1240 & 1060 \\
\hline$L_{9}$ & 3430 & 1595 & 1446 & 1346 & 1182 & 1109 \\
\hline$L_{10}$ & 3448 & 1594 & 1445 & 1320 & 1260 & 1089 \\
\hline$L_{11}$ & 3441 & 1595 & 1446 & 1359 & 1251 & 1072 \\
\hline$L_{12}$ & 3408 & 1594 & 1451 & 1360 & 1281 & 1067 \\
\hline
\end{tabular}


TABle $3:{ }^{1} \mathrm{HNMR}$ spectroscopic data of the ligands $(\delta / \mathrm{ppm})$.

\begin{tabular}{|c|c|c|c|c|c|}
\hline & $\begin{array}{l}2 \mathrm{CH}_{3} \text { groups of } \\
\text { azoform }(\mathrm{d}, 3 \mathrm{H})\end{array}$ & $\begin{array}{c}2 \mathrm{CH}_{3} \text { groups of } \\
\text { hydrazoform }(\mathrm{d}, 3 \mathrm{H})\end{array}$ & $\begin{array}{l}2 \mathrm{CH} \text { groups of } \\
\text { azoform }(\mathrm{d}, 2 \mathrm{H})\end{array}$ & $\begin{array}{c}\text { NH groups of } \\
\text { hydrazoform }\left(\mathrm{D}_{2} \mathrm{O}\right. \\
\text { exchangeable, } \mathrm{s}, 1 \mathrm{H})\end{array}$ & $\begin{array}{l}\text { Aromatic }+ \\
\text { methylenic protons } \\
(\mathrm{m})\end{array}$ \\
\hline$L_{1}$ & 1.588 & 2.50 & 3.41 & broad & $7.12-7.50$ \\
\hline$L_{2}$ & 1.61 & 2.50 & 3.36 & broad & $6.85-7.75$ \\
\hline$L_{3}$ & 1.60 & 2.495 & 3.39 & broad & $6.70-7.60$ \\
\hline$L_{4}$ & 2.00 & 2.44 & 3.52 & broad & $6.71-7.54$ \\
\hline$L_{5}$ & 2.24 & 2.49 & 3.85 & broad & $6.56-7.63$ \\
\hline$L_{6}$ & 1.37 & 2.50 & 4.00 & $4.80,7.77$ & $6.91-7.25$ \\
\hline$L_{7}$ & 1.436 & 2.50 & 3.34 & $4.83,7.98$ & $6.83-7.68$ \\
\hline$L_{8}$ & 1.45 & 2.50 & 3.34 & $4.79,8.21$ & $7.06-7.77$ \\
\hline$L_{9}$ & - & - & 3.45 & - & $6.42-7.97$ \\
\hline$L_{10}$ & - & - & 3.40 & - & $6.62-7.95$ \\
\hline$L_{11}$ & - & - & 3.50 & - & $6.50-7.12$ \\
\hline$L_{12}$ & - & - & 3.38 & - & $7.39-8.23$ \\
\hline
\end{tabular}

TABLE 4: $\mathrm{m} / \mathrm{z}$ values (relative intensities) of the main fragments of the ligands.

\begin{tabular}{|c|c|c|c|c|c|c|c|c|}
\hline & {$[\mathrm{M}]^{+}$} & {$[\mathrm{A}]^{+}$} & {$[\mathrm{B}]^{+}$} & {$[\mathrm{C}]^{+}$} & {$[\mathrm{D}]^{+}$} & {$[\mathrm{E}]^{+}$} & {$[\mathrm{F}]^{+}$} & {$[\mathrm{G}]^{+}$} \\
\hline$L_{1}$ & $\begin{array}{l}386 \\
(11)\end{array}$ & $\begin{array}{l}281 \\
(20)\end{array}$ & $\begin{array}{c}263 \\
(19.0)\end{array}$ & $\begin{array}{c}173 \\
(18.1)\end{array}$ & $\begin{array}{c}131 \\
(10.40)\end{array}$ & $\begin{array}{l}118 \\
(31)\end{array}$ & $\begin{array}{c}92 \\
(12.6)\end{array}$ & $\begin{array}{c}77 \\
(100)\end{array}$ \\
\hline$L_{2}$ & $\begin{array}{c}402 \\
(0.28)\end{array}$ & $\begin{array}{c}297 \\
(4.12)\end{array}$ & $\begin{array}{c}263 \\
(1.01)\end{array}$ & $\begin{array}{c}173 \\
(6.07)\end{array}$ & $\begin{array}{c}131 \\
(3.74)\end{array}$ & $\begin{array}{l}118 \\
(40)\end{array}$ & $\begin{array}{c}92 \\
(15.54)\end{array}$ & $\begin{array}{c}77 \\
(100)\end{array}$ \\
\hline$L_{3}$ & $\begin{array}{c}447 \\
(0.12)\end{array}$ & $\begin{array}{c}342 \\
(1.34)\end{array}$ & $\begin{array}{c}263 \\
(0.79)\end{array}$ & $\begin{array}{c}173 \\
(8.90)\end{array}$ & $\begin{array}{c}131 \\
(2.61)\end{array}$ & $\begin{array}{c}118 \\
(29.64)\end{array}$ & $\begin{array}{c}92 \\
(23.06)\end{array}$ & $\begin{array}{c}77 \\
(100)\end{array}$ \\
\hline$L_{4}$ & $\begin{array}{l}413 \\
(8)\end{array}$ & $\begin{array}{c}308 \\
(12.7)\end{array}$ & $\begin{array}{c}263 \\
(41.1)\end{array}$ & $\begin{array}{c}173 \\
(11.3)\end{array}$ & $\begin{array}{c}131 \\
(12.7)\end{array}$ & $\begin{array}{l}118 \\
(28)\end{array}$ & $\begin{array}{c}92 \\
(53)\end{array}$ & $\begin{array}{c}77 \\
(100)\end{array}$ \\
\hline$L_{5}$ & $\begin{array}{c}448 \\
(1.11)\end{array}$ & $\begin{array}{c}343 \\
(6.1)\end{array}$ & $\begin{array}{c}325 \\
(13.1)\end{array}$ & $\begin{array}{c}234 \\
(16.2)\end{array}$ & $\begin{array}{c}131 \\
(4.4)\end{array}$ & $\begin{array}{c}118 \\
(13.5)\end{array}$ & $\begin{array}{c}92 \\
(7.7)\end{array}$ & $\begin{array}{c}77 \\
(97)\end{array}$ \\
\hline$L_{6}$ & $\begin{array}{c}464 \\
(26.0)\end{array}$ & $\begin{array}{c}359 \\
(22.27)\end{array}$ & $\begin{array}{c}324 \\
(0.19)\end{array}$ & $\begin{array}{c}233 \\
(4.64)\end{array}$ & $\begin{array}{c}131 \\
(0.82)\end{array}$ & $\begin{array}{c}118 \\
(2.57)\end{array}$ & $\begin{array}{c}92 \\
(3.67)\end{array}$ & $\begin{array}{c}77 \\
(100)\end{array}$ \\
\hline$L_{7}$ & $\begin{array}{l}509 \\
18.9\end{array}$ & $\begin{array}{l}404 \\
-\end{array}$ & $\begin{array}{l}325 \\
13.1\end{array}$ & $\begin{array}{l}234 \\
12.5\end{array}$ & $\begin{array}{l}131 \\
1.0\end{array}$ & $\begin{array}{l}118 \\
13.5\end{array}$ & $\begin{array}{l}92 \\
7.7\end{array}$ & $\begin{array}{c}77 \\
97.3\end{array}$ \\
\hline$L_{8}$ & $\begin{array}{c}475 \\
(8.6)\end{array}$ & $\begin{array}{l}370 \\
(2.4)\end{array}$ & $\begin{array}{c}324 \\
(25.9)\end{array}$ & $\begin{array}{c}233 \\
(4.4)\end{array}$ & $\begin{array}{c}131 \\
(1.3)\end{array}$ & $\begin{array}{c}118 \\
(1.0)\end{array}$ & $\begin{array}{l}92 \\
-\end{array}$ & $\begin{array}{c}77 \\
(62)\end{array}$ \\
\hline$L_{9}$ & $\begin{array}{l}510 \\
(8)\end{array}$ & $\begin{array}{l}405 \\
-\end{array}$ & $\begin{array}{c}386 \\
-\end{array}$ & $\begin{array}{c}295 \\
(40.2)\end{array}$ & $\begin{array}{c}193 \\
(11.6)\end{array}$ & $\begin{array}{c}180 \\
(4.2)\end{array}$ & $\begin{array}{c}154 \\
(1.1)\end{array}$ & $\begin{array}{c}77 \\
(72.6)\end{array}$ \\
\hline$L_{10}$ & $\begin{array}{c}527 \\
(3.24)\end{array}$ & $\begin{array}{l}422 \\
-\end{array}$ & $\begin{array}{l}387 \\
(2.8)\end{array}$ & $\begin{array}{c}296 \\
-\end{array}$ & $\begin{array}{c}194 \\
(12.3)\end{array}$ & $\begin{array}{l}181 \\
-\end{array}$ & $\begin{array}{c}155 \\
(2.03)\end{array}$ & $\begin{array}{c}78 \\
(84)\end{array}$ \\
\hline$L_{11}$ & $\begin{array}{c}571 \\
(7.11)\end{array}$ & $\begin{array}{c}466 \\
-\end{array}$ & $\begin{array}{c}386 \\
-\end{array}$ & $\begin{array}{l}295 \\
32.9\end{array}$ & $\begin{array}{l}193 \\
8.6\end{array}$ & $\begin{array}{c}180 \\
25.7\end{array}$ & $\begin{array}{l}154 \\
-\end{array}$ & $\begin{array}{c}77 \\
81.4\end{array}$ \\
\hline$L_{12}$ & $\begin{array}{c}537 \\
{[\mathrm{M}+1]^{+}} \\
(10)\end{array}$ & $\begin{array}{l}432 \\
(8)\end{array}$ & $\begin{array}{c}386 \\
-\end{array}$ & $\begin{array}{l}297 \\
(90)\end{array}$ & $\begin{array}{l}193 \\
(28)\end{array}$ & $\begin{array}{l}180 \\
(4)\end{array}$ & $\begin{array}{l}154 \\
(29)\end{array}$ & $\begin{array}{c}77 \\
(31)\end{array}$ \\
\hline
\end{tabular}

vibrations. Medium intensity bands in the region 1109.24$1060.85 \mathrm{~cm}^{-1}$ are assigned to $\mathrm{N}-\mathrm{N}$ stretching vibrations. It is notable that no bands around $1700 \mathrm{~cm}^{-1}$ are observed which confirms the condensation of $\mathrm{C}=\mathrm{O}$ groups of the Knövenagel condensation with phenylhydrazine $[31,32]$. Two mediumintensity bands corresponding to $\mathrm{C}=\mathrm{C}$ stretching vibrations of the aromatic rings are shown around 1600 and $1500 \mathrm{~cm}^{-1}$. Selected infrared data of the new ligands are listed in Table 2.
The ${ }^{1} \mathrm{H}$ NMR chemical shifts and coupling constants of DMSO- $\mathrm{d}_{6}$ are given in Table 3 suggesting the existence of two tautomeric forms except for ligands $L_{9}-L_{12}$. Two sets of signals are observed for the methyl group for ligands $L_{1}-L_{8}$. The resonance of the $\mathrm{CH}$ groups of the azoform is readily detectable for all ligands, whereas the peaks of the two $\mathrm{NH}$ groups of the hydrazoform $\left(L_{1}-L_{8}\right)$ are broad in the case of $L_{1}-L_{5}$. The above IR and NMR spectroscopic features 


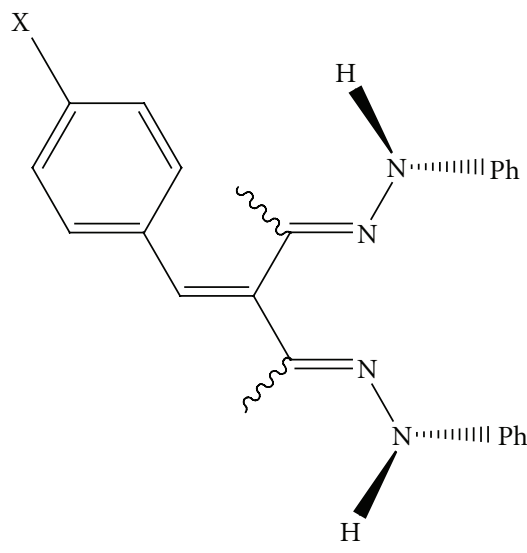

Hydrazoform

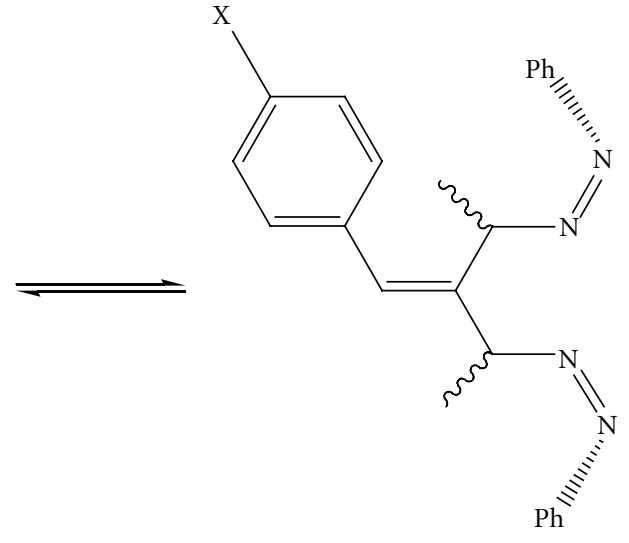

Azoform

FIGURE 1: Tautomerization of the ligands.

point to an azo-hydrazo tautomerism for ligands $L_{1}-L_{8}$ as shown below. Steric hindrance as well as electrondonating properties of the two phenyl groups prevent hydrazoform.

The mass spectroscopic fragmentation pathway of the ligands is shown in Scheme 1. The molecular ions in the mass spectra and their relative abundances are given in Table 4.

Reaction of the ligands $L_{1-2}, L_{4-5}, L_{7-9}$, and $L_{12}$ with $\mathrm{Sc}\left(\mathrm{NO}_{3}\right)_{3} \cdot x \mathrm{H}_{2} \mathrm{O}, \mathrm{Y}\left(\mathrm{NO}_{3}\right)_{3} \cdot 6 \mathrm{H}_{2} \mathrm{O}, \mathrm{Ce}\left(\mathrm{NO}_{3}\right)_{3} \cdot 6 \mathrm{H}_{2} \mathrm{O}$, and $\mathrm{La}\left(\mathrm{NO}_{3}\right)_{3} \cdot 6 \mathrm{H}_{2} \mathrm{O}$ were performed in ethanol. The complexes show $1: 1$ metal-to-ligand ratio as indicated by their elemental analyses. Their physical properties, magnetic moments, and elemental analyses are listed in Table 5 . The results are in agreement with the postulated formulae $( \pm 1 \%)$. Complexes of ligands 3, 6, 10, and 11 cannot be separated in the solid state.

To achieve an idea about the groups involved in complex formation as well as the influence of the electrical field of the central metal ion on the change distribution within the ligand, the spectra of the complexes were carefully compared with those of the ligands.

The IR spectra of all complexes exhibit broad bands around $3748.80-3413.39 \mathrm{~cm}^{-1}$, which are attributed to $\mathrm{O}-\mathrm{H}$ stretching vibrations of the associated water molecules that may be water of hydration or coordinated molecules. $\mathrm{N}-\mathrm{H}$ and $\mathrm{O}-\mathrm{H}$ stretching vibrations of complexes are overlapped for eight complexes. The $\mathrm{N}-\mathrm{H}$ stretching vibrations of the other ten complexes show shifts to wave numbers differing from those of the free ligand $\left(\sim 315-45 \mathrm{~cm}^{-1}\right)$. Red chemical shifts are observed $\left(\sim 7-60 \mathrm{~cm}^{-1}\right)$ which are attributed to $\mathrm{C}=\mathrm{N}$ stretching vibrations. Positive chemical shifts $\left(\sim 10-75 \mathrm{~cm}^{-1}\right)$ is also detected for the $\mathrm{C}=\mathrm{N}$ stretching vibrations and $\mathrm{N}-\mathrm{H}$ inplane bending vibrations. Red shifts for complexes compared with ligands $\left(\sim 6-35 \mathrm{~cm}^{-1}\right),(\sim 5-$ $\left.91 \mathrm{~cm}^{-1}\right)$, and $\left(\sim 7-50 \mathrm{~cm}^{-1}\right)$ are seen for $\mathrm{N}=\mathrm{N}$ stretching vibrations, $\mathrm{N}-\mathrm{H}$ inplane bending vibrations, and $\mathrm{N}-\mathrm{N}$ stretching vibrations, respectively. All these shifts in infrared spectra of the complexes compared with those of the ligands suggest coordination through the two lone pairs of electrons of the two $\mathrm{sp}^{2}$ nitrogen atoms of the hydrazoform as a bidentate ligand forming two stable six-membered rings. The infrared spectral data of the complexes are listed in Table 6.

The thermograms of the complexes show a loss of hygroscopic water molecules from 85 to $105^{\circ} \mathrm{C}$. The anhydrous complexes show thermal stability up to $130^{\circ} \mathrm{C}$. Removal of coordinated water molecules takes place at $130-260^{\circ} \mathrm{C}$. The coordinated water molecules are found to be one for complexes Sc- $L_{1}$, two for complexes Ce- $L_{1}$, Y- $L_{5}$, three for complexes Sc- $L_{7}, \mathrm{La}-L_{7}, \mathrm{La}-L_{9}$, and Ce- $L_{12}$, four for complexes Sc- $L_{9}$ and Sc- $L_{12}$, and five for complexes Y- $L_{4}$, Ce$L_{4}$, Y- $L_{4}$, Ce- $L_{9}$, and La- $L_{12}$. TG shows no coordinated water molecules in the complexes Sc- $L_{2}, \mathrm{Y}-L_{8}, \mathrm{Y}-L_{9}$, and Y- $L_{12}$.

The magnetic moments of complexes given in Table 7 suggest diamagnetic characters for $\mathrm{Sc}(\mathrm{III}), \mathrm{Y}(\mathrm{III})$, and $\mathrm{La}$ (III) complexes whereas $\mathrm{Ce}(\mathrm{III})$ complexes have paramagnetic characters ranging from $2.42-2.26 \mathrm{~J} \cdot \mathrm{T}^{-1}$ [33] being consistent with mononuclear complexes and free from antiferromagnetism. The deviation of the values from the theoretical value suggests that the $4 \mathrm{f}$ electron participate in the bond formation of the metal to the ligand.

The thermogravimetric results given in Table 7 and the elemental analyses suggest that Sc- $L_{2}$ and Y- $L_{8}$ complexes complete their coordination sphere by ammonia molecules, Y- $L_{9}$ complete its coordination sphere by ethanol molecules and Sc- $L_{1}, \mathrm{Ce}-L_{1}, \mathrm{Y}-L_{4}$, Ce- $L_{4}, \mathrm{Y}-L_{5}, \mathrm{Sc}-L_{7}, \mathrm{La}-L_{7}, \mathrm{La}-L_{8}$, Sc- $L_{9}$, Ce- $L_{9}$, La- $L_{9}$, Sc- $L_{12}$, La- $L_{12}$, and Ce- $L_{12}$ complexes complete their coordination sphere by water molecules. Y$L_{12}$ complex complete its coordination sphere by ammonia and ethanol molecules.

Conductivity measurements using conductivity meter of platinum electrodes for mmol concentrations of complex solutions in $D M F$ at $25^{\circ} \mathrm{C}$ show that Sc- $L_{1}, \mathrm{Ce}-L_{1}, \mathrm{Y}-L_{5}, \mathrm{Y}-$ $L_{8}, \mathrm{Y}-L_{9}$, and $\mathrm{Y}-L_{12}$ are neutral, whereas other complexes measure $\sim 213.42-197.63 \mathrm{~cm}^{3} \cdot \mathrm{Ohm}^{-1} \cdot \mathrm{mol}^{-1}$, suggesting the presence of free nitrate anions.

Elemental analyses, conductivity measurements, magnetic susceptibility measurements, and thermogravimetry of the complexes reinforce each other; suggesting octahedral 
<smiles>[X]c1ccc(C=C(C(C)N=Nc2ccccc2)C(C)N=Nc2ccccc2)cc1</smiles>

$[\mathrm{M}]$

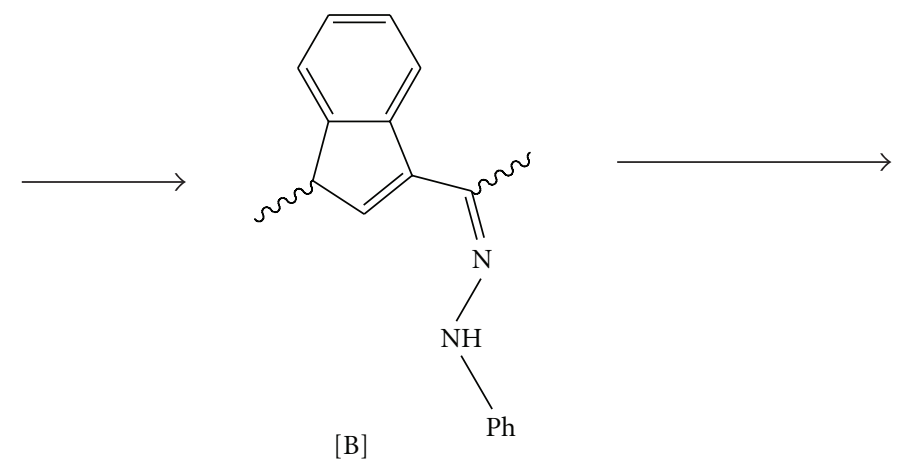<smiles>CC1C=Cc2ccccc21</smiles>

[D]<smiles>Cc1ccccc1</smiles>

[F]

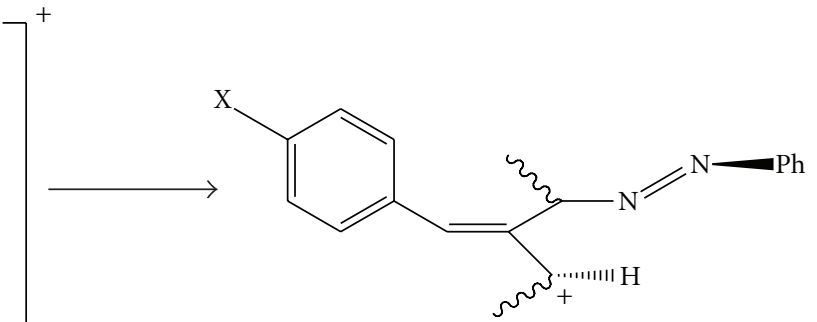

$[\mathrm{A}]$<smiles>CC1C=C(C(=N)O)c2ccccc21</smiles>

$[\mathrm{C}]$<smiles>C/C=C\c1ccccc1</smiles>

$[\mathrm{E}]$<smiles>c1ccccc1</smiles>

$[\mathrm{G}]$

Scheme 1: The general route of fragmentation of ligands.

geometry with coordination number 6 for the complexes Sc- $L_{1}$, Sc- $L_{2}$, Sc- $L_{7}, \mathrm{La}-L_{7}, \mathrm{Y}-L_{8}, \mathrm{Sc}-L_{9}$, and Sc- $L_{12}$, whereas they suggest distorted pentagonal bipyramid structure with coordination number 7 for other complexes [34].

In the light of the above discussion, representative structures of the complexes may be as follow:

The metal complexes and standard drugs (ampicillin, tetracycline, and salicylic acid) were tested for their antimicrobial activity at a concentration of $60 \mu \mathrm{g} \mathrm{mL}^{-1}$ in DMF using the paper disc diffusion method $[35,36]$. The diameter of the susceptibility zones was measured, and the results are given in Table 8 . The susceptibility zones measured were the clear zones around the discs inhibiting the microbial growth. It is clear that Scandium(III) complexes are more active towards bacterium, yeast, and fungi. Because of the relatively large positive charge density on Scandium atom, it is partially shared with the donor nitrogen atoms of the ligands, and there is $\pi$-electron delocalization over the whole chelate ring [36, 37]. This in turn, increases its permeation through the lipoid layers of the microorganism membranes. Other factors such as solubility, conductivity, and dipole moment may also increasing activity $[36,37]$. Representative structures of the complexes are given in Figure 2.

\section{Methodology}

3.1. Chemicals and Equipments. The required 3-benzylidene2,4-pentanedione, 3-benzylidene-1-phenyl-1,3-butandione, and 3-benzyllidene-1,3-diphenyl-1,3-propanedione were 
TABLE 5: Physical properties, magnetic moments, and elemental analyses of complexes.

\begin{tabular}{|c|c|c|c|c|c|c|c|}
\hline \multirow[t]{2}{*}{ Complex (formula weight) } & \multirow[t]{2}{*}{ Color } & \multirow[t]{2}{*}{$\mathrm{MP} /{ }^{\circ} \mathrm{C}$} & \multirow[t]{2}{*}{ Yield $\%$} & \multirow{2}{*}{$\begin{array}{l}\mu \text { eff. BM found } \\
\text { (calc.) }\end{array}$} & \multicolumn{3}{|c|}{ Elemental analyses found (calc.) } \\
\hline & & & & & $\% \mathrm{C}$ & $\% \mathrm{H}$ & $\% \mathrm{~N}$ \\
\hline $\mathrm{Sc}\left[\mathrm{C}_{24} \mathrm{H}_{25} \mathrm{~N}_{7} \mathrm{O}_{10} \mathrm{~F}\right](635.51)$ & White & 255 & 60 & - & $\begin{array}{c}46.27 \\
(45.35)\end{array}$ & $\begin{array}{c}3.70 \\
(3.93)\end{array}$ & $\begin{array}{c}15.14 \\
(15.43)\end{array}$ \\
\hline $\mathrm{Ce}\left[\mathrm{C}_{24} \mathrm{H}_{27} \mathrm{~N}_{7} \mathrm{O}_{11} \mathrm{~F}\right](747.9)$ & Yellow & 302 & 64 & $2.31(2.54)$ & $\begin{array}{c}36.81 \\
(35.50)\end{array}$ & $\begin{array}{c}3.95 \\
(3.61)\end{array}$ & $\begin{array}{c}13.11 \\
(13.10)\end{array}$ \\
\hline $\mathrm{Sc}\left[\mathrm{C}_{24} \mathrm{H}_{29} \mathrm{~N}_{8} \mathrm{O}_{6} \mathrm{Cl}\right] \mathrm{NO}_{3}(667.54)$ & White & 308 & 72 & - & $\begin{array}{c}44.06 \\
(43.14)\end{array}$ & $\begin{array}{c}5.13 \\
(4.34)\end{array}$ & $\begin{array}{c}18.26 \\
(18.87)\end{array}$ \\
\hline $\mathrm{Y}\left[\mathrm{C}_{24} \mathrm{H}_{33} \mathrm{~N}_{5} \mathrm{O}_{7}\right]\left(\mathrm{NO}_{3}\right)_{3} \cdot 3 \mathrm{H}_{2} \mathrm{O}(831.86)$ & $\begin{array}{l}\text { Yellow- } \\
\text { orange }\end{array}$ & 288 & 78 & - & $\begin{array}{c}35.81 \\
(34.62)\end{array}$ & $\begin{array}{c}3.87 \\
(4.69)\end{array}$ & $\begin{array}{c}14.07 \\
(13.46)\end{array}$ \\
\hline $\mathrm{Ce}\left[\mathrm{C}_{24} \mathrm{H}_{33} \mathrm{~N}_{5} \mathrm{O}_{7}\right]\left(\mathrm{NO}_{3}\right)_{3} \cdot 8 \mathrm{H}_{2} \mathrm{O}(973.12)$ & Gray & 294 & 77 & $2.26(2.54)$ & $\begin{array}{c}30.81 \\
(29.60)\end{array}$ & $\begin{array}{c}4.35 \\
(5.04)\end{array}$ & $\begin{array}{c}12.45 \\
(11.51)\end{array}$ \\
\hline $\mathrm{Y}\left[\mathrm{C}_{29} \mathrm{H}_{29} \mathrm{~N}_{7} \mathrm{O}_{11} \mathrm{~F}\right](757.01)$ & White & 313 & 62 & - & $\begin{array}{c}45.22 \\
(45.97)\end{array}$ & $\begin{array}{c}3.74 \\
(3.83)\end{array}$ & $\begin{array}{c}13.22 \\
(12.95)\end{array}$ \\
\hline $\mathrm{Sc}\left[\mathrm{C}_{29} \mathrm{H}_{31} \mathrm{~N}_{5} \mathrm{O}_{6} \mathrm{Br}\right] \mathrm{NO}_{3}(731.95)$ & Yellow & 289 & 54 & - & $\begin{array}{c}46.92 \\
(44.54)\end{array}$ & $\begin{array}{c}4.74 \\
(4.23)\end{array}$ & $\begin{array}{c}11.35 \\
(12.48)\end{array}$ \\
\hline $\mathrm{La}\left[\mathrm{C}_{29} \mathrm{H}_{31} \mathrm{~N}_{5} \mathrm{O}_{6} \mathrm{Br}\right]\left(\mathrm{NO}_{3}\right)_{2}(887.91)$ & White & 301 & 81 & - & $\begin{array}{c}37.92 \\
(39.19)\end{array}$ & $\begin{array}{c}3.74 \\
(3.49)\end{array}$ & $\begin{array}{c}10.46 \\
(11.04)\end{array}$ \\
\hline $\mathrm{Y}\left[\mathrm{C}_{29} \mathrm{H}_{28} \mathrm{~N}_{9} \mathrm{O}_{11}\right] \cdot 0.5 \mathrm{H}_{2} \mathrm{O}(775.95)$ & Yellow & 296 & 58 & - & $\begin{array}{c}45.88 \\
(44.85)\end{array}$ & $\begin{array}{c}4.21 \\
(3.74)\end{array}$ & $\begin{array}{c}15.99 \\
(16.24)\end{array}$ \\
\hline $\mathrm{La}\left[\mathrm{C}_{29} \mathrm{H}_{35} \mathrm{~N}_{5} \mathrm{O}_{7}\right]\left(\mathrm{NO}_{3}\right)_{3}(889.98)$ & $\begin{array}{l}\text { Yellow- } \\
\text { white }\end{array}$ & 293 & 87 & - & $\begin{array}{c}40.15 \\
(39.10)\end{array}$ & $\begin{array}{c}4.21 \\
(3.93)\end{array}$ & $\begin{array}{c}13.42 \\
(12.58)\end{array}$ \\
\hline $\mathrm{Sc}\left[\mathrm{C}_{34} \mathrm{H}_{35} \mathrm{~N}_{4} \mathrm{O}_{4} \mathrm{~F}\right]\left(\mathrm{NO}_{3}\right)_{3} \cdot 7 \mathrm{H}_{2} \mathrm{O}(938.83)$ & White & 314 & 60 & - & $\begin{array}{c}42.15 \\
(43.46)\end{array}$ & $\begin{array}{c}5.31 \\
(5.22)\end{array}$ & $\begin{array}{c}10.70 \\
(10.44)\end{array}$ \\
\hline $\mathrm{Y}\left[\mathrm{C}_{38} \mathrm{H}_{39} \mathrm{~N}_{7} \mathrm{O}_{11} \mathrm{~F}\right](877)$ & White & 287 & 65 & - & $\begin{array}{c}52.15 \\
(52.00)\end{array}$ & $\begin{array}{c}4.85 \\
(4.47)\end{array}$ & $\begin{array}{c}10.90 \\
(11.18)\end{array}$ \\
\hline $\mathrm{La}\left[\mathrm{C}_{34} \mathrm{H}_{33} \mathrm{~N}_{6} \mathrm{O}_{9} \mathrm{~F}\right]\left(\mathrm{NO}_{3}\right) \cdot 4 \mathrm{H}_{2} \mathrm{O}(960.85)$ & Black & 299 & 76 & - & $\begin{array}{c}43.55 \\
(42.42)\end{array}$ & $\begin{array}{c}4.99 \\
(4.27)\end{array}$ & $\begin{array}{c}11.11 \\
(10.20)\end{array}$ \\
\hline $\mathrm{Ce}\left[\mathrm{C}_{34} \mathrm{H}_{37} \mathrm{~N}_{4} \mathrm{O}_{5} \mathrm{~F}\right]\left(\mathrm{NO}_{3}\right)_{3} \cdot \mathrm{H}_{2} \mathrm{O}(944)$ & $\begin{array}{l}\text { Yellow- } \\
\text { white }\end{array}$ & 301 & 66 & $2.42(2.54)$ & $\begin{array}{c}43.31 \\
(43.22)\end{array}$ & $\begin{array}{c}4.58 \\
(3.91)\end{array}$ & $\begin{array}{c}12.21 \\
(10.38)\end{array}$ \\
\hline $\mathrm{Sc}\left[\mathrm{C}_{34} \mathrm{H}_{35} \mathrm{~N}_{5} \mathrm{O}_{6}\right]\left(\mathrm{NO}_{3}\right)_{3} \cdot \mathrm{H}_{2} \mathrm{O}(857.79)$ & White & 305 & 79 & - & $\begin{array}{c}48.22 \\
(47.57)\end{array}$ & $\begin{array}{c}3.86 \\
(4.38)\end{array}$ & $\begin{array}{c}(13.05) \\
14.31\end{array}$ \\
\hline $\mathrm{Y}\left[\mathrm{C}_{38} \mathrm{H}_{39} \mathrm{~N}_{8} \mathrm{O}_{13}\right](903.69)$ & White & 317 & 79 & - & $\begin{array}{c}51.60 \\
(50.44)\end{array}$ & $\begin{array}{c}4.27 \\
(4.31)\end{array}$ & $\begin{array}{c}14.04 \\
(12.39)\end{array}$ \\
\hline $\mathrm{La}\left[\mathrm{C}_{34} \mathrm{H}_{37} \mathrm{~N}_{5} \mathrm{O}_{7}\right]\left(\mathrm{NO}_{3}\right)_{3} \cdot 3 \mathrm{H}_{2} \mathrm{O}(1011.91)$ & White & 306 & 63 & - & $\begin{array}{c}42.20 \\
(43.83)\end{array}$ & $\begin{array}{c}3.99 \\
(3.22)\end{array}$ & $\begin{array}{l}10.16 \\
(11.85)\end{array}$ \\
\hline $\mathrm{Ce}\left[\mathrm{C}_{34} \mathrm{H}_{33} \mathrm{~N}_{6} \mathrm{O}_{11}\right]\left(\mathrm{NO}_{3}\right) \cdot \mathrm{H}_{2} \mathrm{O}(935.0)$ & Brown & 288 & 72 & $2.37(2.54)$ & $\begin{array}{c}45.27 \\
(43.63)\end{array}$ & $\begin{array}{c}4.38 \\
(3.52)\end{array}$ & $\begin{array}{c}10.44 \\
(11.90)\end{array}$ \\
\hline
\end{tabular}

synthesized as described previously [32]. The Schiff bases were prepared by condensation with phenylhydrazine (BDH, England) in dry absolute ethanol (Riedel-de Haën) in presence of $\mathrm{HCl}$ (Riedel-de Haën) as a catalyst [31]. $\mathrm{Sc}\left(\mathrm{NO}_{3}\right)_{3} \cdot x \mathrm{H}_{2} \mathrm{O}$ 99\%, $\mathrm{Y}\left(\mathrm{NO}_{3}\right)_{3} \cdot 6 \mathrm{H}_{2} \mathrm{O} \quad 99 \%$, $\mathrm{Ce}\left(\mathrm{NO}_{3}\right)_{3} \cdot 6 \mathrm{H}_{2} \mathrm{O} 99 \%$, and $\mathrm{La}\left(\mathrm{NO}_{3}\right)_{3} \cdot 6 \mathrm{H}_{2} \mathrm{O} 97 \%$ were purchased from BDH. 4-chloro-benzaldehyde 97\% (Fluka), 4fluorobenzaldehyde 98\% (BDH), 4-nitrobenzaldehyde $98 \%$ (BDH), 4-bromobenzaldehyde 99\% (BDH), 1,3-diphenyl1,3-propandion 98\% (BDH), phenyl-1,3-butanedion 99\% $(\mathrm{BDH})$, and acetylacetone $99 \%$ (WINLAB) were also used. All other solvents used were of the ANALAR grade. Elemental analyses were performed at King Saud University, Saudi Arabia. Melting points were recorded on a Gallenkamp melting point apparatus. IR spectra were recorded on Perkin
Elmer (spectrum 1000) FT-IR spectrometer using $\mathrm{KBr}$ pellets at the chemistry department, College of Science, King Fahd University for Petroleum and Minerals Saudi Arabia. Proton NMR spectra were recorded using JEOl EX-270 MHz (DMSO- $\mathrm{d}_{6}$ ) with TMS as an internal reference. Mass spectra were recorded with the aid of GCMS-QP 1000 EX Shimadzu spectrophotometer at $70 \mathrm{eV}$ using a direct insertion probe at $25-300^{\circ} \mathrm{C}$ at the Microanalytical Centre, Cairo University, Egypt. Thermogravimetric analyses were measured under nitrogen flow rate: $30 \mathrm{~cm}^{3} \mathrm{~min}^{-1}$ using a Shimadzu TGA$60 \mathrm{H}$ thermobalance from room temperature up to $1000^{\circ} \mathrm{C}$ at the chemistry department, college of Science, King Faisal University Saudi Arabia. The magnetic susceptibilities were measured using a Sherwood Scientific Ltd. Magnetic susceptibility balance (England). 
TABLe 6: Selected infrared data of complexes $\left(\mathrm{cm}^{-1}\right)$.

\begin{tabular}{|c|c|c|c|c|c|c|c|}
\hline Complexes & $v(\mathrm{O}-\mathrm{H})$ & $v(\mathrm{~N}-\mathrm{H})$ & $v(\mathrm{C}=\mathrm{N})$ & $v(\mathrm{C}-\mathrm{N})+\delta(\mathrm{N}-\mathrm{H})$ & $v(\mathrm{~N}=\mathrm{N})$ & $\delta(\mathrm{N}-\mathrm{H})$ & $v(\mathrm{~N}-\mathrm{N})$ \\
\hline Sc- $L_{1}$ & 3425 & overlap & 1598 & 1503 & 1365 & 1225 & 1079 \\
\hline Ce- $L_{1}$ & 3427 & overlap & 1596 & 1499 & 1397 & 1248 & 1069 \\
\hline Sc- $L_{2}$ & 3445 & 3208 & 1613 & 1493 & 1360 & 1281 & 1067 \\
\hline $\mathrm{Y}-L_{4}$ & 3445 & 3300 & 1610 & 1503 & 1381 & 1227 & 1097 \\
\hline $\mathrm{Ce}-L_{4}$ & 3611 & overlap & 1648 & 1457 & 1372 & 1228 & 1157 \\
\hline Y- $L_{5}$ & 3748 & overlap & 1609 & 1505 & 1382 & 1235 & 1156 \\
\hline Sc- $-L_{7}$ & 3450 & 3331 & 1596 & 1490 & 1382 & 1235 & 1072 \\
\hline $\mathrm{La}-L_{7}$ & 3423 & overlap & 1606 & 1499 & 1379 & 1253 & 1089 \\
\hline $\mathrm{Y}-L_{8}$ & 3455 & 3395 & 1597 & 1512 & 1345 & 1224 & 1062 \\
\hline $\mathrm{La}-L_{8}$ & 3538 & 3342 & 1594 & 1511 & 1382 & 1246 & 1105 \\
\hline Sc- $L_{9}$ & 3500 & 3448 & 1617 & 1492 & 1365 & 1242 & 1113 \\
\hline $\mathrm{Y}-L_{9}$ & 3540 & 3116 & 1592 & 1444 & 1361 & 1210 & 1168 \\
\hline La- $L_{9}$ & 3523 & overlap & 1609 & 1494 & 1383 & 1211 & 1020 \\
\hline Ce- $L_{9}$ & 3413 & 3115 & 1591 & 1489 & 1356 & 1208 & 1168 \\
\hline Sc- $L_{12}$ & 3435 & overlap & 1594 & 1491 & 1360 & 1290 & 1067 \\
\hline $\mathrm{Y}-L_{12}$ & 3427 & overlap & 1596 & 1499 & 1379 & 1248 & 1069 \\
\hline $\mathrm{La}-L_{12}$ & 3430 & 3430 & 1603 & 1496 & 1383 & 1347 & 1106 \\
\hline $\mathrm{Ce}-L_{12}$ & 3500 & 3412 & 1653 & 1492 & 1383 & 1299 & 1087 \\
\hline
\end{tabular}

TABLE 7: Thermogravimetric results of the complexes.

\begin{tabular}{|c|c|c|c|c|c|c|c|c|}
\hline \multirow[b]{2}{*}{ Complexes } & \multicolumn{4}{|c|}{ Hygroscopic water } & \multicolumn{4}{|c|}{ Coordinated water } \\
\hline & $T /{ }^{\circ} \mathrm{C}$ & $\%$ Weig & at loss & No. of water molecule & $T /{ }^{\circ} \mathrm{C}$ & \% Weig & toss & No. of water molecule \\
\hline $\mathrm{Sc}\left[L_{1}\left(\mathrm{NO}_{3}\right)_{3}\left(\mathrm{H}_{2} \mathrm{O}\right)\right]$ & - & - & - & - & $130-235$ & 2.62 & 2.78 & 1 \\
\hline $\mathrm{Ce}\left[L_{1}\left(\mathrm{NO}_{3}\right)_{3}\left(\mathrm{H}_{2} \mathrm{O}\right)_{2}\right]$ & 一 & - & - & - & Up to 220 & 4.89 & 4.72 & 2 \\
\hline $\mathrm{Sc}\left[L_{2}\left(\mathrm{NO}_{3}\right)_{2}\left(\mathrm{NH}_{3}\right)_{2}\right] \mathrm{NO}_{3}$ & 一 & - & - & - & 一 & 一 & - & 一 \\
\hline $\mathrm{Y}\left[L_{4}\left(\mathrm{H}_{2} \mathrm{O}\right)_{5}\right]\left(\mathrm{NO}_{3}\right)_{3} \cdot 3 \mathrm{H}_{2} \mathrm{O}$ & 92 & 6.18 & 6.49 & 3 & $130-210$ & 9.20 & 10.82 & 5 \\
\hline $\mathrm{Ce}\left[L_{4}\left(\mathrm{H}_{2} \mathrm{O}\right)_{5}\right]\left(\mathrm{NO}_{3}\right)_{3} \cdot 8 \mathrm{H}_{2} \mathrm{O}$ & 90 & 14.20 & 12.80 & 8 & $130-210$ & 10.20 & 9.25 & 5 \\
\hline $\mathrm{Y}\left[L_{5}\left(\mathrm{NO}_{3}\right)_{3}\left(\mathrm{H}_{2} \mathrm{O}\right)_{2}\right]$ & - & - & - & 一 & $160-210$ & 3.99 & 4.78 & 2 \\
\hline $\mathrm{Sc}\left[L_{7}\left(\mathrm{NO}_{3}\right)\left(\mathrm{H}_{2} \mathrm{O}\right)_{3}\right]\left(\mathrm{NO}_{3}\right)_{2}$ & - & - & - & - & $170-220$ & 6.42 & 7.38 & 3 \\
\hline $\mathrm{La}\left[L_{7}\left(\mathrm{NO}_{3}\right)\left(\mathrm{H}_{2} \mathrm{O}\right)_{3}\right]\left(\mathrm{NO}_{3}\right)_{2}$ & - & - & - & - & $180-240$ & 6.49 & 6.08 & 3 \\
\hline $\mathrm{Y}\left[L_{8}\left(\mathrm{NO}_{3}\right)_{3}\left(\mathrm{NH}_{3}\right)\right] \cdot 0.5 \mathrm{H}_{2} \mathrm{O}$ & 98 & 1.13 & 1.16 & 0.5 & - & - & 一 & - \\
\hline $\mathrm{La}\left[L_{8}\left(\mathrm{H}_{2} \mathrm{O}\right)_{5}\right]\left(\mathrm{NO}_{3}\right)_{3}$ & - & - & - & - & $190-250$ & 11.63 & 10.11 & 5 \\
\hline $\mathrm{Sc}\left[L_{9}\left(\mathrm{H}_{2} \mathrm{O}\right)_{4}\right]\left(\mathrm{NO}_{3}\right)_{3} \cdot 7 \mathrm{H}_{2} \mathrm{O}$ & 90 & 14.60 & 13.42 & 7 & $140-210$ & 6.22 & 7.67 & 4 \\
\hline $\mathrm{Y}\left[L_{9}\left(\mathrm{NO}_{3}\right)_{3}\left(\mathrm{C}_{2} \mathrm{H}_{5} \mathrm{OH}\right)_{2}\right]$ & - & - & - & 一 & - & - & - & 一 \\
\hline $\mathrm{La}\left[L_{9}\left(\mathrm{NO}_{3}\right)_{2}\left(\mathrm{H}_{2} \mathrm{O}\right)_{3}\right]\left(\mathrm{NO}_{3}\right) \cdot 4 \mathrm{H}_{2} \mathrm{O}$ & 85 & 7.00 & 7.49 & 4 & $130-160$ & 5.58 & 5.62 & 3 \\
\hline $\mathrm{Ce}\left[L_{9}\left(\mathrm{H}_{2} \mathrm{O}\right)_{5}\right]\left(\mathrm{NO}_{3}\right)_{3} \cdot \mathrm{H}_{2} \mathrm{O}$ & 105 & 2.47 & 1.95 & 1 & $160-220$ & 8.95 & 9.73 & 5 \\
\hline $\mathrm{Sc}\left[L_{12}\left(\mathrm{H}_{2} \mathrm{O}\right)_{4}\right]\left(\mathrm{NO}_{3}\right)_{3} \cdot \mathrm{H}_{2} \mathrm{O}$ & 100 & 2.05 & 2.10 & 1 & $160-260$ & 9.19 & 8.39 & 4 \\
\hline $\mathrm{Y}\left[L_{12}\left(\mathrm{NO}_{3}\right)_{3}\left(\mathrm{C}_{2} \mathrm{H}_{5} \mathrm{OH}\right)_{2}\right]$ & - & - & - & 一 & - & - & 一 & - \\
\hline $\mathrm{La}\left[L_{12}\left(\mathrm{H}_{2} \mathrm{O}\right)_{5}\right]\left(\mathrm{NO}_{3}\right)_{3} \cdot 3 \mathrm{H}_{2} \mathrm{O}$ & 95 & 4.00 & 5.37 & 3 & $130-160$ & 11.70 & 10.95 & 5 \\
\hline $\mathrm{Ce}\left[\mathrm{L}_{12}\left(\mathrm{NO}_{3}\right)_{2}\left(\mathrm{H}_{2} \mathrm{O}\right)_{3}\right]\left(\mathrm{NO}_{3}\right) \cdot \mathrm{H}_{2} \mathrm{O}$ & 100 & 2.17 & 1.95 & 1 & $130-220$ & 5.20 & 5.86 & 3 \\
\hline
\end{tabular}

3.2. Preparation of the Ligands. Condensation of substituted $\left\{p-\mathrm{F}(1), p-\mathrm{Cl}(2), p-\mathrm{Br}(3)\right.$, and $\left.p-\mathrm{NO}_{2}(4)\right\}$ 3-benzylidene-2, 4-pentanedione (I), 3-benzylidene-1-phenyl-1,3-butandione (II), and 3-benzyllidene-1,3-diphenyl-1,3-propanedione (III) with phenylhydrazine (see equation below) was performed by refluxing $20 \mathrm{mmol}$ solution of the carbonyl compounds
$\left(\mathrm{I}_{1}=4.124, \mathrm{I}_{2}=4.453, \mathrm{I}_{3}=5.342, \mathrm{I}_{4}=4.662 \mathrm{~g}\right),\left(\mathrm{II}_{1}=5.363\right.$, $\left.\mathrm{II}_{2}=5.690, \mathrm{II}_{3}=6.581, \mathrm{II}_{4}=5.903 \mathrm{~g}\right)$, and $\left(\mathrm{III}_{1}=6.604\right.$, $\left.\mathrm{III}_{2}=6.932, \mathrm{III}_{3}=7.822, \mathrm{III}_{4}=7.140 \mathrm{~g}\right)$ with $40 \mathrm{mmol}$ phenylhydrazine $\left(3.93 \mathrm{~cm}^{3}\right)$ in $30 \mathrm{~cm}^{3}$ absolute ethanol in presence of $5 \mathrm{~cm}^{3}$ concentrated $\mathrm{HCl}$ as a catalyst for $18-$ $24 \mathrm{~h}$. The solution was then cooled to room temperature 
TABLE 8: Antimicrobial activity data for the complexes*.

\begin{tabular}{|c|c|c|c|c|c|c|}
\hline Complex & B. subtilis & S. aureus & E. coli & S. typhi & A. niger & C. albicans \\
\hline Sc- $L_{1}$ & 15 & 7 & 10 & 6 & + & ++ \\
\hline $\mathrm{Ce}-L_{1}$ & 9 & - & 7 & - & + & + \\
\hline Sc $-L_{2}$ & 10 & 6 & 6 & 11 & ++ & ++ \\
\hline $\mathrm{Y}-L_{4}$ & 7 & 7 & 7 & 7 & + & + \\
\hline Ce- $L_{4}$ & 6 & - & 7 & 6 & + & ++ \\
\hline $\mathrm{Y}-L_{5}$ & 10 & 7 & 6 & 8 & - & + \\
\hline Sc- $-L_{7}$ & 11 & 10 & 10 & 12 & + & + \\
\hline $\mathrm{La}-L_{7}$ & 6 & - & - & 6 & - & - \\
\hline $\mathrm{Y}-L_{8}$ & 6 & 8 & 8 & 8 & + & + \\
\hline $\mathrm{La}-L_{8}$ & 6 & 7 & 6 & 6 & + & - \\
\hline Sc- $L_{9}$ & 12 & 11 & 12 & 12 & + & + \\
\hline$Y-L_{9}$ & 14 & 9 & 13 & 9 & + & + \\
\hline $\mathrm{La}-L_{9}$ & 6 & - & - & - & + & + \\
\hline $\mathrm{Ce}-L_{9}$ & 7 & 6 & 6 & 6 & + & + \\
\hline Sc- $L_{12}$ & 17 & 10 & 10 & 15 & ++ & +++ \\
\hline $\mathrm{Y}-L_{12}$ & 11 & 11 & 10 & 8 & + & ++ \\
\hline $\mathrm{La}-L_{12}$ & 11 & 7 & 7 & - & - & ++ \\
\hline Ce- $L_{12}$ & 12 & 9 & 10 & 7 & ++ & +++ \\
\hline Ampicillin & 18 & 16 & 15 & 14 & - & - \\
\hline Tetracycline & 16 & 15 & 17 & 17 & - & - \\
\hline Salicylic Acid & - & - & - & - & ++++ & ++++ \\
\hline
\end{tabular}

* Inhibition zone diameter (\% inhibition): +, 6-9 mm (33-50\%); ++, 10-12 mm (55-67\%); +++, 13-15 mm (72-83); ++++, 16-18 mm (89-100\%).

Percentage inhibition values were relative to inhibition zone $(18 \mathrm{~mm})$ with $100 \%$ inhibition.

and added in portions with continuous stirring to crushed ice prepared from bidistilled water. The resulting yield was filtered, washed with water, and recrystallized from ethanol until constant melting point. Color, MP., yield, and elemental analyses are given in Table 1.

3.3. General Procedure for the Complexes. A solution containing $5 \mathrm{mmol}$ of ligand in $40 \mathrm{~cm}^{3}$ ethanol was refluxed with a solution of $7 \mathrm{mmol}$ of $\mathrm{Sc}(\mathrm{III}), \mathrm{Y}(\mathrm{III}), \mathrm{La}(\mathrm{III})$, and $\mathrm{Ce}(\mathrm{III})$ nitrates for about $12 \mathrm{~h}$ after adjusting the $\mathrm{pH}$ using ammonia $(1: 1)$ or Thiel Buffer [38] solution, cooled to room temperature, filtered, washed with ethanol and water, recrystallized from ethanol, and dried on air. The physical properties of the prepared complexes were very stable under ordinary conditions.

\subsection{Antimicrobial Studies}

3.4.1. Preparation of the Discs. The complex $(60 \mu \mathrm{g})$ in DMF $\left(0.01 \mathrm{~cm}^{3}\right)$ was mounted on a paper disc (prepared from blotting paper $(5 \mathrm{~mm}$ diameter $)$ ) with the help of micropipette. The discs were left at room temperature till dryness and then applied on the microorganism-grown agar plates.
3.4.2. Preparation of Agar Plates. Minimal agar was used for the growth of specific microbial species. The preparation of agar plates for B. subtilis, S. aureus, E. coli, and S. typhi (bacteria) utilized nutrient agar (2.30 g; obtained from Panreac Quimica SA, Spain) suspended in freshly distilled water $\left(100 \mathrm{~cm}^{3}\right)$ and potato dextrose agar medium $\left(3.9 \mathrm{~g} / 100 \mathrm{~cm}^{3}\right.$; obtained from Merck) for A. niger and C. albicans (fungi). This was allowed to soak for $15 \mathrm{~min}$ and then boiled on a water bath until the agar was completely dissolved. The mixture was autoclaved for $15 \mathrm{~min}$ at $120^{\circ} \mathrm{C}$, then poured into previously washed and sterilized Petri dishes, and stored at $30^{\circ} \mathrm{C}$ for inoculation.

3.4.3. Procedure of Inoculation. Inoculation was done with the help of platinum wire loop, which was heated to red-hot in a flame, cooled and then used for the application of the microbial strains.

3.4.4. Application of the Discs. Sterilized forceps were used for the application of the paper disc on previously inoculated agar plates. When the discs were applied, they were incubated at $37^{\circ} \mathrm{C}$ for $24 \mathrm{~h}$ for bacteria and yeast and at $28^{\circ} \mathrm{C}$ for $48 \mathrm{~h}$ for fungi. The zone of inhibition around the disc was then measured in millimeters [35]. 


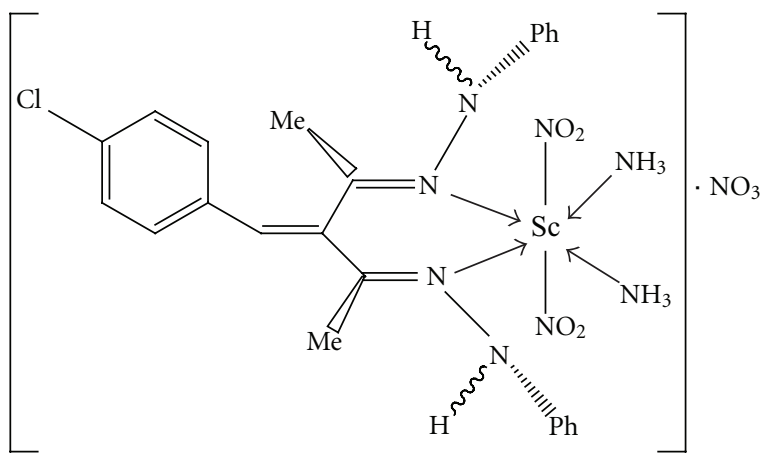

(a)

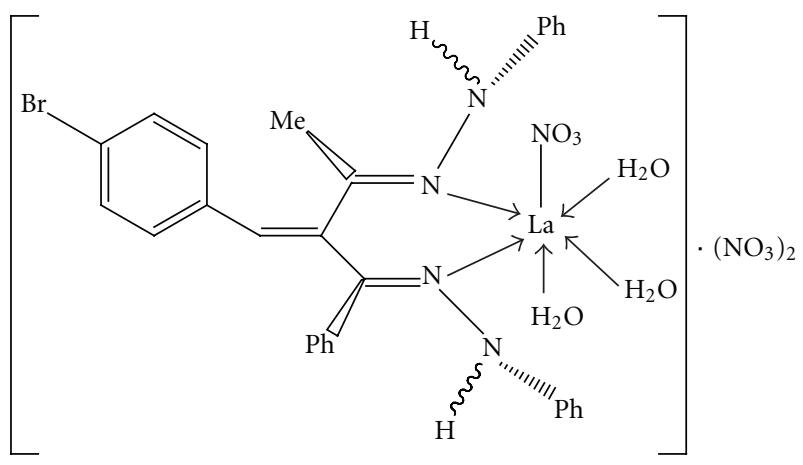

(b)

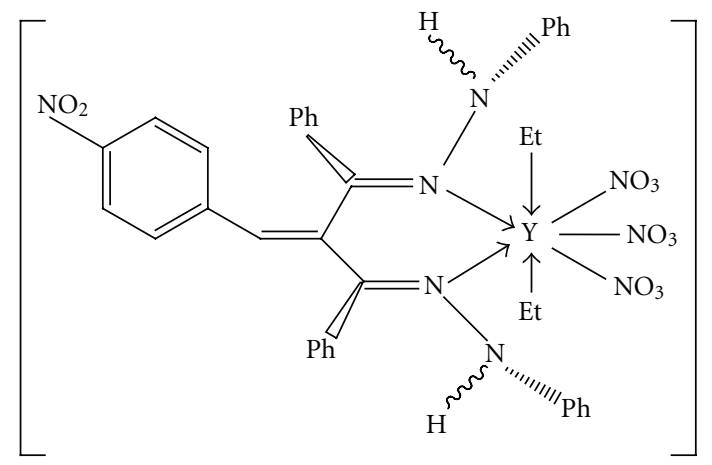

(c)

FIgURE 2: Representative structures of the complexes.

\section{Acknowledgment}

The authors wish to express their deep thanks to the King Abdul-Aziz City for Science and Technology (KACST), Riyadh, Saudi Arabia for providing support to this scientific research.

\section{References}

[1] K. Desai and B. T. Thaker, "Synthesis and characterisation of new mixed azomethyne Schiff base complexes of cobalt(II), nickel(II) and copper(II) and their pyridine adducts involving $\beta$-diketones as ligands," Journal of the Indian Chemical Society, vol. 67, no. 8, pp. 667-669, 1990.

[2] M. Lamrani, G. Mousset, E. Leize, and A. Van Dorsselaer, "Synthesis, characterization, and electrochemical study of new iron (III) complexes with benzoylacetone-3- and salycyloylhydrazone," New Journal of Chemistry, vol. 19, pp. 313-323, 1995.

[3] M. H. Attari, M. S. Mubarak, and F. I. Khalili, "Preparation and characterization of some tetradentate Schiff bases and their complexes with $\mathrm{Co}(\mathrm{II}), \mathrm{Ni}(\mathrm{II})$ and $\mathrm{Cu}(\mathrm{II})$," Synthesis and Reactivity in Inorganic and Metal-Organic Chemistry, vol. 27, no. 1, pp. 1-16, 1997.

[4] L. Zhang, D. Chen, D. Xu, and Y. Xu, "Synthesis of 3Aryl-5-t-butylsalicylaldehydes and their Chiral Schiff Base Compounds," Huaxue Wuli Xuebao, vol. 9, p. 522, 1996.

[5] C. Li, N. Kanehisa, Y. Miyagi et al., "Syntheses, structures, and properties of the dinuclear copper(ii) and nickel(ii) complexes bridged by an alkoxide and a pyridazine or a phthalazine," Bulletin of the Chemical Society of Japan, vol. 70, no. 10, pp. 2429-2436, 1997.

[6] E. S. Ibrahim, S. A. Sallam, A. S. Orabi, B. A. El-Shetary, and A. Lentz, "Schiff bases of acetone derivatives: spectroscopic properties and physical constants," Monatshefte fur Chemie, vol. 129, no. 2, pp. 159-171, 1998.

[7] I. Levitin and M. Tsikalova, "Alkylcobalt chelates with Schiff bases derived from a $\beta$-diketone bearing both alkyl and aryl groups," Inorganica Chimica Acta, vol. 270, no. 1-2, pp. 169176, 1998.

[8] E. Pereira, L. Gomes, and B. J. de-Castro, "Synthesis, spectroscopic and electrochemical study of nickel-(II) and (I) complexes with Schiff-base ligands giving a NN'OS coordination sphere," Journal of the Chemical Society-Dalton Transactions, no. 4, pp. 629-636, 1998.

[9] X. G. Zhou, J. S. Huang, P. H. Ko, K. K. Cheung, and C. M. Che, "Titanium and ruthenium binaphthyl Schiff base complexes as catalysts for asymmetric trimethylsilylcyanation of aldehydes," Journal of the Chemical Society-Dalton Transactions, no. 18, pp. 3303-3309, 1999.

[10] J. R. Anacona and R. Brito, "Cadmium(II) and mercury(II) paramagnetic macrocyclic complexes containing a hexaaza Schiff base ligand," Main Group Metal Chemistry, vol. 22, no. 4, pp. 243-246, 1999.

[11] A. Campos, J. R. Anacona, and M. M. Vallette, "Synthesis and IR study of a zinc(II) complex containing a tetradentate macrocyclic Schiff base ligand: antifungal properties," Main Group Metal Chemistry, vol. 22, no. 5, pp. 283-288, 1999.

[12] A. Taha, "Metal complexes of triazine Schiff bases: synthetic, thermodynamic, spectroscopic, and electrochemical studies on complexes of some divalent and trivalent metal ions of 3-( $\alpha$-benzoylbenzylidenhydrazino)-5,6diphenyl-1,2,4-triazine," Synthesis and Reactivity in Inorganic and Metal-Organic Chemistry, vol. 31, no. 2, pp. 205-218, 2001.

[13] Y. W. Zhao and H. L. Yuan, "Synthesis and antitumor activity of beta-diketonato complexes of titanium," Yao Xue Xue Bao, vol. 28, no. 5, pp. 397-399, 1993.

[14] Y. M. Issa and W. H. Hegazy, "Synthesis and spectroscopic studies of $\mathrm{TiO}(\mathrm{II}), \mathrm{VO}(\mathrm{II})$, and $\mathrm{Cr}(\mathrm{III})$ complexes with some $\beta$-diketone dihydrazone derivatives," Synthesis and Reactivity in Inorganic and Metal-Organic Chemistry, vol. 31, no. 2, pp. 303-314, 2001.

[15] S. K. Sengupta, O. P. Pandey, A. Rai, and A. Sinha, "Synthesis, spectroscopic, thermal and antifungal studies on lanthanum(III) and praseodymium(III) derivatives of 1,1diacetylferrocenyl hydrazones," Spectrochimica Acta-Part A, vol. 65, no. 1, pp. 139-142, 2006. 
[16] A. S. El-Tabl, F. A. EL-Saied, and A. N. AL-Hakimi, "Synthesia, spectroscopic investigation and biological activity of metal complexes with ONO trifunctionalalized hydrazone ligand," Transition Metal Chemistry, vol. 32, p. 689, 2007.

[17] Q. Gao-fei, Y. Zheng-yin, and W. Bao-dui, "Synthesis, characterization and DNA-binding properties of $\operatorname{zinc}($ II) and nickel(II) Schiff base complexes," Transition Metal Chemistry, vol. 32, pp. 233-239, 2007.

[18] A. S. El-Tabl, F. A. El-Saied, W. Plass, and A. N. AlHakimi, "Synthesis, spectroscopic characterization and biological activity of the metal complexes of the Schiff base derived from phenylaminoacetohydrazide and dibenzoylmethane," Spectrochimica Acta-Part A, vol. 71, no. 1, pp. 90 99, 2008.

[19] V. P. Singh and A. Katiyar, "Synthesis, spectral characterization and antimicrobial activity of some transition metal(II) complexes with acetone p-amino acetophenone benzoylhydrazone," Pesticide Biochemistry and Physiology, vol. 92, no. 1, pp. 8-14, 2008.

[20] S. A. Schuetz, M. A. Erdmann, V. W. Day, J. L. Clark, and J. A. Belot, "Anhydrous tetranuclear, dinuclear, and dimeric lanthanide complexes bearing tetradentate Schiff bases," Inorganica Chimica Acta, vol. 357, no. 13, pp. 4045-4056, 2004.

[21] X. Li and R. Yang, "Synthesis of ion association complexes of lanthanide ions with 1,5-bis-(1'-phenyl-3'-methyl-5'pyrazolone-4')-1,5-pentanedione and cetyltrimethyl ammonium bromide and their UV, IR, ${ }^{1} \mathrm{H}$ NMR, fluorescence and thermal analysis studies ," Polyhedron, vol. 11, no. 12, pp. 1545-1550, 1992.

[22] A. Bellusci, G. Barberio, A. Crispini, M. Ghedini, M. L. Deda, and D. Pucci, "Synthesis and luminescent properties of novel lanthanide(III) $\beta$-diketone complexes with nitrogen p,p'-disubstituted aromatic ligands," Inorganic Chemistry, vol. 44, no. 6, pp. 1818-1825, 2005.

[23] A. A. Ansari, Z. Ahmed, and K. Iftikhar, "Nuclear magnetic resonance and optical absorption spectroscopic studies on paramagnetic praseodymium(III) complexes with $\beta$-diketone and heterocyclic amines," Spectrochimica Acta-Part A, vol. 68, no. 1, pp. 176-183, 2007.

[24] G. B. Drew Michael, R. Foreman Mark, J. Hudson Michael, and K. F. Kennedy, "Structural studies of lanthanide complexes with tetradentate nitrogen ligands," Inorganica Chimica Acta, vol. 357, no. 14, pp. 4102-4112, 2004.

[25] D. G. Paschalidis, I. A. Tossidis, and M. Gdaniec, "Synthesis, characterization and spectra of lanthanide(III) hydrazone complexes: the X-ray molecular structures of the erbium(III) complex and the ligand," Polyhedron, vol. 19, no. 26-27, pp. 2629-2637, 2000.

[26] R. K. Agarwal, L. Singh, D. K. Sharma, and R. Singh, "Synthesis, spectral and thermal investigations of some oxovanadium(IV) complexes of hydrazones of isonicotinic acid hydrazide," Turkish Journal of Chemistry, vol. 29, pp. 309-316, 2005.

[27] K. Krishnankutty, P. Sayudevi, and M. B. Ummathur, "Metal complexes of Schiff's bases derived from 3-arylazo-2,4pentanediones with 2-aminophenol and 2-aminothiophenol," Journal of the Serbian Chemical Society, vol. 72, pp. 1075-1084, 2007.

[28] S. Mario, S. Obdulia, H. Herbert et al., "New boronates prepared from 2,4-pentanedione derived ligands of the NO and NO type-comparison to the complexes obtained from the corresponding salicylaldehyde derivatives," Journal of Organometallic Chemistry, vol. 689, no. 4, pp. 811-822, 2004.
[29] T. Xi-shi, W. Huiqin, S. Xiaozheng, and T. Minyu, "Synthesis and spectral characterization of methyl-2-pyridyl ketone benzoyl hydrazone and its complexes with rare earth nitrates," Spectroscopy Letters, vol. 38, no. 4, pp. 497-504, 2005.

[30] M. S. Refaat and A. A. Ibrahim, "Synthesis, infrared spectra and thermal studies of $\mathrm{Zn}(\mathrm{II}), \mathrm{Cd}(\mathrm{II})$ and $\mathrm{Hg}(\mathrm{II})$ complexes with 2-aminobenzaldehyde phenylhydrazone "nitrin" ligand," Spectrochimica Acta-Part A, vol. 70, pp. 234-242, 2008.

[31] W. H. Hegazy, "Synthesis and structural studies of some $\beta$ diketone phenylhydrazones and their complexes with $\mathrm{Co}(\mathrm{II})$, $\mathrm{Ni}(\mathrm{II})$, and $\mathrm{Cu}(\mathrm{II})$, " Monatshefte fur Chemie, vol. 132, no. 5, pp. 639-650, 2001.

[32] Y. M. Issa and W. H. Hegazy, "Preparation and characterization of some substituted 3-benzylidene-2,4-pentanediones and some of their metal complexes," Synthesis and Reactivity in Inorganic and Metal-Organic Chemistry, vol. 30, no. 9, pp. 1731-1746, 2000.

[33] A. G. Sharpe, Inorganic Chemistry, Longman, New York, NY, USA, 3rd edition, 1994.

[34] F. A. Cotton, G. Willkinson, C. A. Marillo, and M. Bockmann, Advanced Inorganic Chemistry, John Wiley \& Sons, New York, NY, USA, 6th edition, 1999.

[35] M. M. Abd-Elzaher, "Synthesis, characterization, and antimicrobial activity of cobalt(II), nickel(II), copper(II) and zinc(II) complexes with ferrocenyl Schiff bases containing a phenol moiety," Applied Organometallic Chemistry, vol. 18, pp. 149155, 2004.

[36] Z. H. Chohan and M. A. Farooq, "Synthesis, characterization, ligational and biological properties of some acylhydrazine derived furanyl and thienyl Schiff bases with $\mathrm{Co}(\mathrm{II}), \mathrm{Cu}(\mathrm{II})$, $\mathrm{Ni}(\mathrm{II})$, and $\mathrm{Zn}(\mathrm{II})$ metal ions," Synthesis and Reactivity in Inorganic and Metal-Organic Chemistry, vol. 31, no. 10, pp. 1853-1871, 2001.

[37] Z. H. Chohan and S. Kausar, "Synthesis, characterization and biological properties of tridentate NNO, NNS and NNN donor thiazole-derived furanyl, thiophenyl and pyrrolyl Schiff bases and their $\mathrm{Co}(\mathrm{II}), \mathrm{Cu}(\mathrm{II}), \mathrm{Ni}(\mathrm{II})$ and $\mathrm{Zn}(\mathrm{II})$ metal chelates," Metal-Based Drugs, vol. 7, no. 1, pp. 17-22, 2000.

[38] H. T. S. Britton, Hydrogen Ions, Chapman and Hall, London, UK, 4th edition, 1952. 


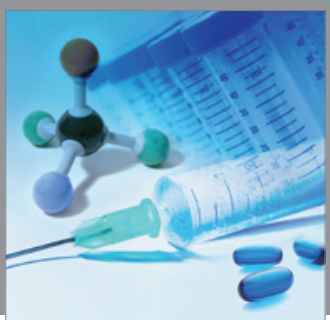

International Journal of

Medicinal Chemistry

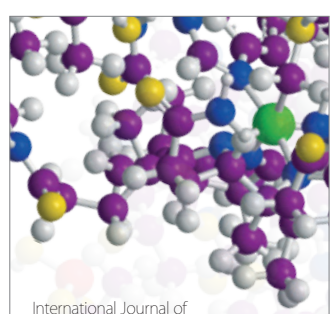

Carbohydrate Chemistry

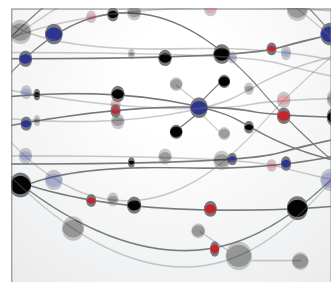

The Scientific World Journal
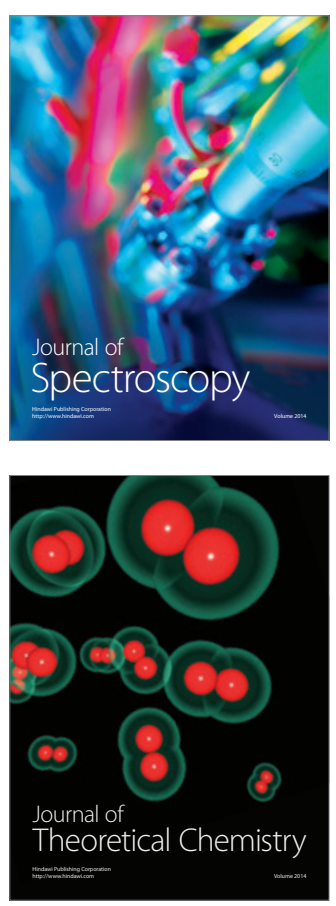
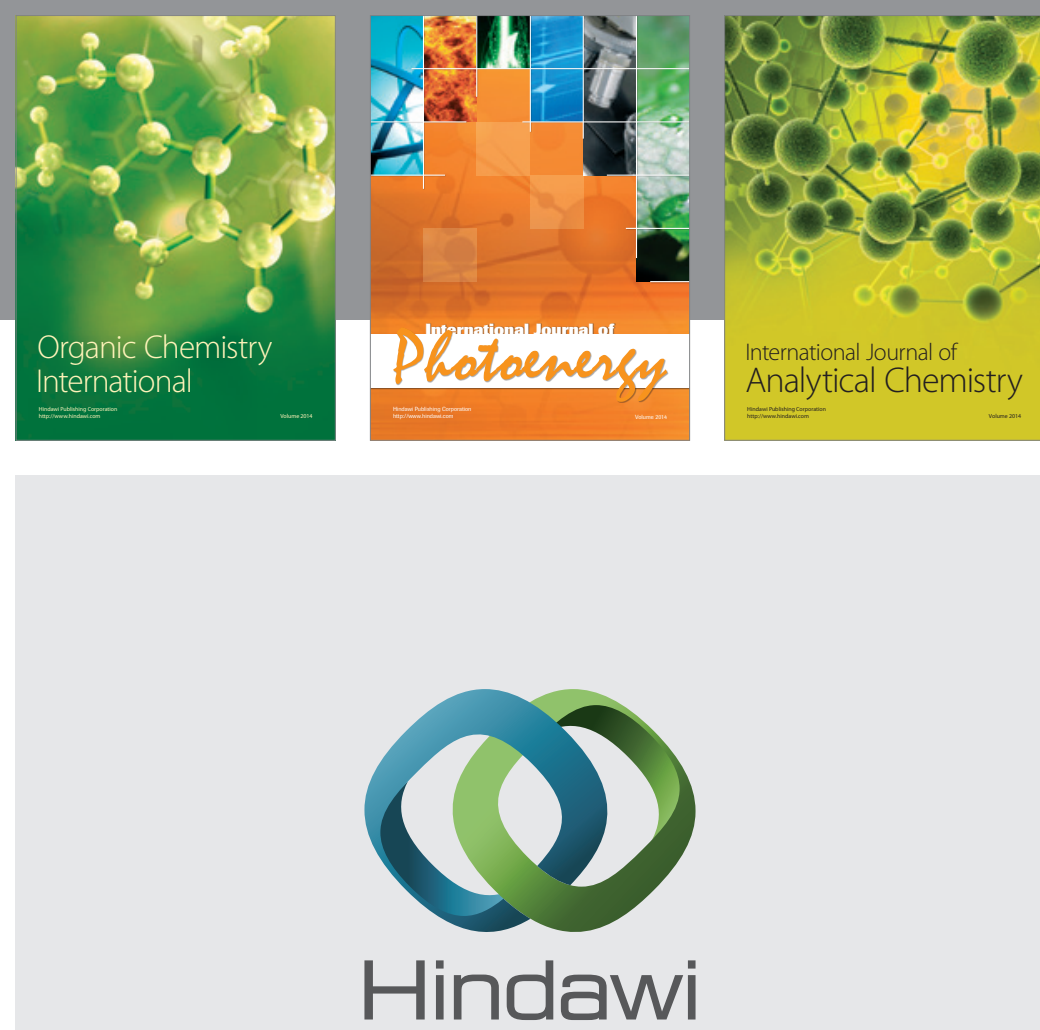

Submit your manuscripts at

http://www.hindawi.com
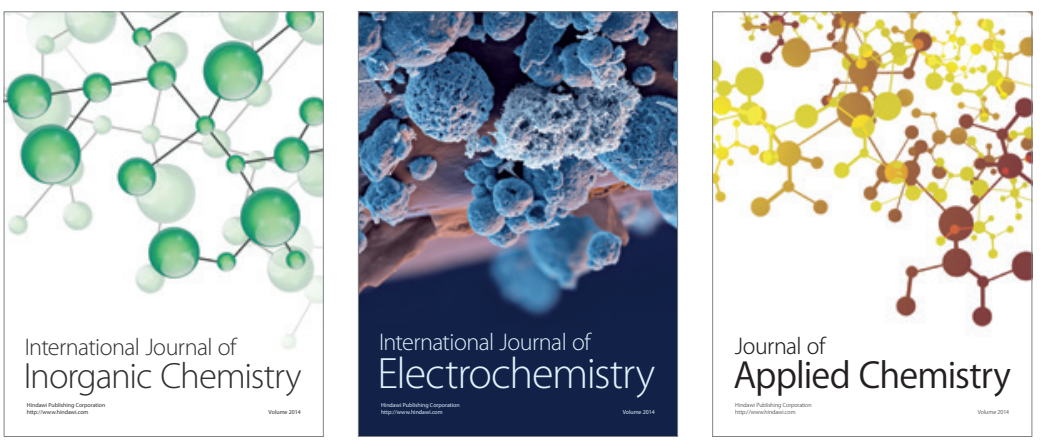

Journal of

Applied Chemistry
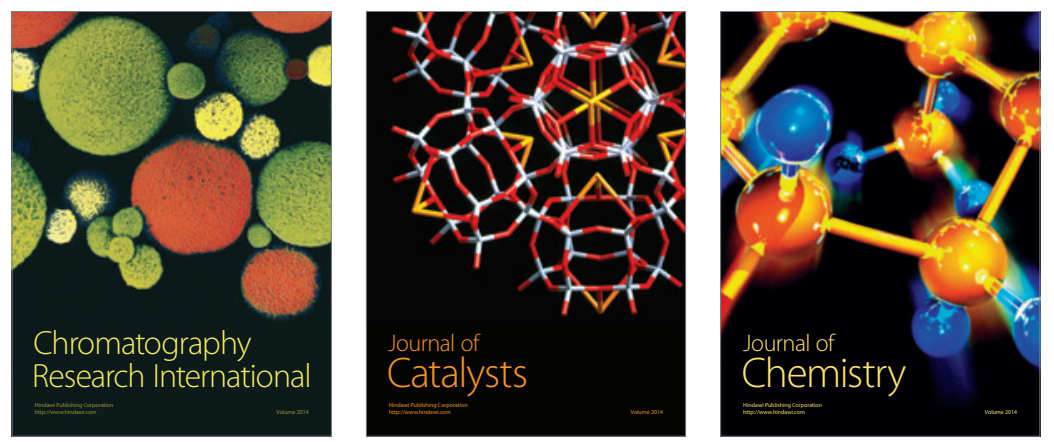
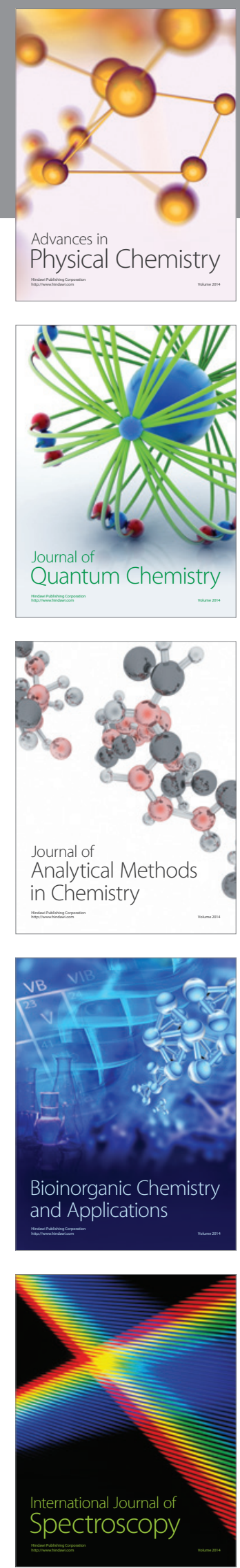